International Journal of Technology 11(3) 631-641 (2020)

Received January 2020 / Revised January 2020 / Accepted May 2020

International Journal of Technology

http://ijtech.eng.ui.ac.id

\title{
What Drives Individuals to Dispose of Waste Mobile Phones? A Case Study in Indonesia
}

\author{
Romadhani Ardi $1^{*}$, Billy Muhamad Iqbal ${ }^{1}$, Sekarsyifa Sesarea ${ }^{1}$, Komarudin ${ }^{1}$ \\ ${ }^{1}$ Department of Industrial Engineering, Faculty of Engineering, Universitas Indonesia, Kampus UI Depok, \\ Depok 16424, Indonesia
}

\begin{abstract}
While end-of-life mobile phones make up a growing fraction of the total volume of waste electrical and electronic equipment (WEEE) generated worldwide, their collection rate remains low. In order to address this problem, it is necessary to understand individual consumers' disposal behaviors, especially in the context of developing countries. Accordingly, the aim of this study is to assess the determinants of disposal behaviors regarding waste mobile phones in a country lacking well-established systems. This study conceptualizes a model based on the theory of planned behavior and proposes five types of disposal behaviors: keeping, reselling, donating, recycling, and discarding. Models were tested using a survey administered to residents of Jakarta, Indonesia. Through use of structural equation modeling, this study shows that improving environmental awareness can stimulate subsequent responsible disposal behaviors. It also reveals that throwing waste mobile phones into mixed bins is common practice in Indonesia.
\end{abstract}

Keywords: Confirmatory factor analysis; Disposal behavior; Structural equation modeling; Theory of planned behavior; Waste electrical and electronic equipment (WEEE); Waste mobile phones

\section{Introduction}

In recent years, global society has witnessed a rapid growth in the electronics industry with the advance of technology. Therefore, it is only natural that the amount of waste electrical and electronic equipment (WEEE) being generated is also increasing at an alarming level (Ardi and Leisten, 2016). To prevent WEEE from contaminating the environment, societies needs to handle the problem of WEEE with specific management systems. It is estimated, however, that only $20 \%$ of the total WEEE volume worldwide is recycled properly (Baldé et al., 2017). The fate of unrecycled WEEE remains unknown; however, as these numbers indicate, WEEE is becoming a critical problem in many countries because most of the unrecycled waste could contaminate soil, water and air (Ardi, 2016). This is especially true in developing countries such as Indonesia, which tend to be characterized by a lack of infrastructure and a low rate of recycling (Magista et al., 2018; Prabowo et al., 2019).

One type of WEEE that merits special attention is waste mobile phones. Sales of mobile phones are increasing at a rate of over $40 \%$ per year (Xu et al., 2016). In Indonesia, the penetration levels of primary and internet-capable mobile phones have reached $98 \%$ and $78 \%$ of households, respectively (Puspitasari and Ishii, 2016). It is not out of the question

${ }^{*}$ Corresponding author's email: romadhani.ardi@ui.ac.id, Tel.: +62-2178888805, Fax.: +62-2178885656 doi: 10.14716/ijtech.v11i3.3855 
that Indonesia will have generated over 40 million end-of-life mobile phone units by 2028 (Santoso et al., 2019).

Every mobile phone contains hazardous elements, including lead, mercury, arsenic, polychlorinated biphenyls, and fluorinated cooling fluids, as well as potentially recoverable precious materials, such as gold, silver, copper, and palladium (Nnorom et al., 2009; Sarath et al., 2015). However, among all types of WEEE, waste mobile phones are the most difficult to collect in the formal recycling sector because, for a variety of reasons, many consumers keep their obsolete mobile phones in their households (Polák and Drápalová, 2012; Wilson et al., 2017).

Currently, the Indonesian government incorporates WEEE into its general regulations on hazardous waste, which are challenging to enforce owing to a lack of well-developed systems (Yunita et al., 2019). If the current situation continues without intervention, informal recycling businesses might begin to flourish, and it then could threaten the official systems. One crucial initiative necessary for motivating solutions is understanding residents' disposal behaviors. This is a key factor for the development of an improved waste management system (Chi et al., 2014). Many scholarly works rely on the theory of planned behavior (TPB) to predict disposal behaviors (Ari and Yilmaz, 2016). The TPB model includes an analysis of the underlying factors that shape an individual's intentions and their subsequent behaviors, including attitude (AT), subjective norms (SN), and perceived behavioral control (PBC).

Several studies have used and expanded upon the basic TPB relationships to analyze disposal behaviors. Borthakur and Govind (2018) analyzed Bangalorean residents' public understanding of WEEE disposal using the conventional TPB model and, interestingly, argue that $\mathrm{PBC}$ could not be a driver of disposal intentions because of an absence of information regarding recycling programs available to consumers. In contrast, Ari and Yilmaz (2016), who used Turkish housewives as their respondents, reveal that in this case PBC (together with SN) actually was a determinant of recycling behavior. Wang et al. (2016), in their Chinese case study, extend the TPB model's factors by including environmental awareness and by breaking down PBC into convenience of recycling, cost of recycling, and perception of informal recycling. Though the new PBC variables were significant in their case study, these details are not yet relevant in Indonesia because of the absence of regulation, lack of infrastructure, and a relatively less dominant informal sector when compared with China (Chi et al., 2014; Yunita et al., 2019).

Seacat and Nortrup (2010) incorporated motivation as a predictor of recycling behaviors. The present study here also employs motivation as a proposed determinant because obligation-based intrinsic motivation is particularly applicable for environmental behavior considerations, and because the world recognizes Indonesian citizens as some of the most frequent participants in volunteering causes (Devina, 2018; Van der Werff et al., 2013). Aminrad et al. (2013) and de la Vega (2004) show that environmental awareness influences environmental knowledge and attitude. Aminrad et al. (2013) and Goudeau (2014) argue that environmental knowledge has a positive impact on attitude and motivation. Hence, it is crucial to consider environmental awareness and environmental knowledge in surveying Indonesians in an urban setting because the educated group there has relatively better knowledge and higher awareness toward environmental problems than its general public living (Sudarmadi et al., 2001).

Using an extended model of TPB, this study aims to identify the factors that influence disposal behaviors regarding end-of-life mobile phones and the relationships among these factors. It collects a set of data from a survey administered to the residents of Jakarta and then subjects the data to structural equation modeling (SEM) analysis to reveal causal relationships. The remainder of this paper is organized as follows: Section 2 consists of a literature review regarding the status of waste mobile phone management, WEEE disposal 
behaviors in general, studies on TPB and SEM. Section 3 explains the methodology used in this study to conceptualize the model and survey procedures. Section 4 discusses the results of confirmatory factor analysis (CFA) and path analysis in SEM. Finally, the last section outlines the crucial findings of this study and offers insights for future studies.

\section{Literature Review}

The official recycling system pay more attention to end-of-life mobile phones than other forms of WEEE because of the associated significant economic opportunities and their low collection rate (Baxter and Gram-Hanssen, 2016; Cucchiella et al., 2016). Since the introduction of pioneering works by the Swiss SWICO Recycling program in 1999, many other industrial nations have developed initiatives to manage waste mobile phone, either by conducting collection projects, by including mobile phones in WEEE-specific regulations, or by analyzing the disposal behaviors of residents (Borthakur and Govind, 2017; Sarath et al., 2015).

Disposal behaviors for generic WEEE have been reported quite extensively in the literature, but discussions specific to waste mobile phones are limited (Pérez-Belis et al., 2014; Sarath et al., 2015). Li et al. (2012), one of the few existing studies on this topic, attempts to assess disposal behaviors regarding retired mobile phones based on the experiences of Chinese university students. The authors surveyed 1,011 respondents and found not only that most respondents replaced their mobile phones after two or three years of usage, but also that most of them stockpiled their retired mobile phones in their houses. Sarath et al. (2015), in a comprehensive review, reported on the limited number of studies on disposal behaviors regarding waste mobile phones based on analyses done in China, Germany, Nigeria, and Europe. These authors noted that the collection rate of retired mobile phones remains limited in most countries. Borthakur and Govind (2017) examined consumers' disposal behaviors in developed and developing countries and found that the situations were drastically different between these countries.

The theory of planned behavior, from Ajzen (1991), is an extension of the theory of reasoned action. It includes an analysis of perceived behavioral control, which describes the perceived difficulty of an actor when conducting the behavior of interest (Xu et al., 2017). This notion is somewhat parallel to the concept of the psychological contract, in which an employee's perception of what he or she will contribute to an organization and what he or she will gain in return are factors seen to influence the employee's behavior (Anvari et al., 2013). Previous works have studied WEEE disposal behaviors from a TPB perspective, including a study on the causes of positive intentions and recycling behaviors in Brazil (Echegaray and Hansstein, 2017). Using an extended version of TPB on a sample of 806 households, the Brazilian study revealed that although most respondents had positive intentions regarding responsible disposal behaviors, only a few of them behaved accordingly in practice. Likewise, Borthakur and Govind (2018) surveyed 300 purposely selected respondents from India. They found that while most participants had positive intentions regarding WEEE recycling, only a small fraction of them were aware of the existing Indian WEEE regulations, which contributed to problems in the official collection.

Structural equation modeling (SEM) is a general statistical modeling methodology that combines factor analysis and path analysis to understand the relationships between theoretical constructs. Previous works have utilized SEM to assess the disposal behaviors of WEEE in several countries, including Pakistan, Turkey, and China (Kochan and Prybutok, 2016; Wang et al., 2016; Gilal et al., 2019). 


\section{Methodology}

\subsection{Model Conceptualization}

This study utilizes a model that integrates TPB with other models, as depicted in Figure 1.

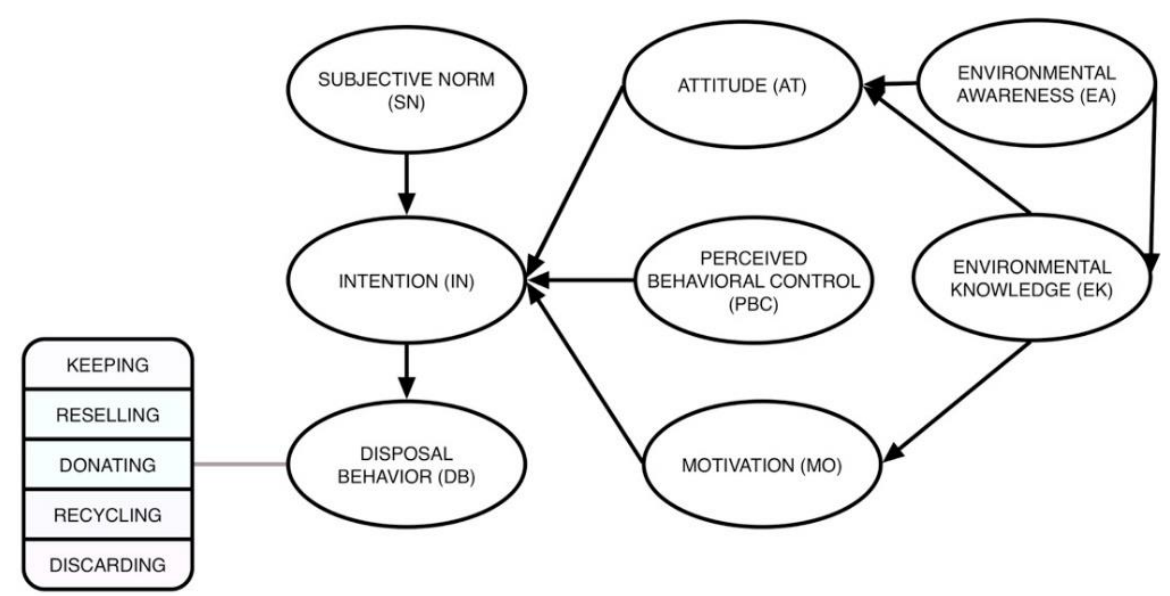

Figure 1 Model conceptualization under investigation

1) This study defines intention (IN) as a person's willingness to dispose of his/her mobile phone using formal systems (Wang et al., 2016).

2) Attitude (AT) toward a behavior is how a person evaluates the disposal behavior itself (Ajzen, 1991; Wang et al., 2016).

3) Subjective norm (SN) is a person's perception of the beliefs of other people, which could influence his/her intention to engage in responsible disposal behaviors (Borthakur and Govind, 2018).

4) Perceived behavioral control (PBC) refers to a person's perception of whether it is difficult or easy to dispose of a waste mobile phone (Ajzen, 1991; Borthakur and Govind, 2018).

5) Disposal behavior (DB) in this study is extended based on the model of disposition decision taxonomy presented in Jacoby et al. (1977). Accordingly, this study breaks down disposal behavior into five specific disposal modes: keeping, reselling, donating, recycling, and discarding.

6) Motivation (MO) in this study is "the energizing force that activates behavior and provides purpose and direction to that behavior" (Seacat and Northrup, 2010; Shim, 1995).

7) Environmental awareness (EA) is a sensitivity to environmental issues (Athman and Monroe, 2001).

8) This study defines environmental knowledge (EK) as a deeper understanding of the basics of environmental issues (Athman and Monroe, 2001).

After selecting the model constructs, the hypotheses presented in Table 1 were proposed to assess relationships that could help predict the selected disposal behaviors. 
Table 1 The proposed hypotheses under study

\begin{tabular}{|c|c|c|c|}
\hline Hypothesis & Relationship & Notation & Reference \\
\hline H1 & $\begin{array}{l}\text { Environmental awareness has a } \\
\text { significant effect on attitude }\end{array}$ & $\mathrm{EA} \rightarrow \mathrm{AT}$ & Aminrad et al. (2013) \\
\hline $\mathrm{H} 2$ & $\begin{array}{l}\text { Environmental awareness has a } \\
\text { significant effect on environmental } \\
\text { knowledge }\end{array}$ & $\mathrm{EA} \rightarrow \mathrm{EK}$ & $\begin{array}{l}\text { Aminrad et al. (2013), de } \\
\text { la Vega (2004) }\end{array}$ \\
\hline H3 & $\begin{array}{l}\text { Environmental knowledge has a } \\
\text { significant effect on attitude }\end{array}$ & $\mathrm{EK} \rightarrow \mathrm{AT}$ & Aminrad et al. (2013) \\
\hline $\mathrm{H} 4$ & $\begin{array}{l}\text { Environmental knowledge has a } \\
\text { significant effect on motivation }\end{array}$ & $\mathrm{EK} \rightarrow \mathrm{MO}$ & Goudeau (2014) \\
\hline H5 & $\begin{array}{l}\text { Attitude has a significant effect on } \\
\text { intention }\end{array}$ & $\mathrm{AT} \rightarrow \mathrm{IN}$ & Ajzen (1991) \\
\hline H6 & $\begin{array}{l}\text { Subjective norm has a significant effect } \\
\text { on intention }\end{array}$ & $\mathrm{SN} \rightarrow \mathrm{IN}$ & Ajzen (1991) \\
\hline H7 & $\begin{array}{l}\text { Perceived behavioral control has a } \\
\text { significant effect on intention }\end{array}$ & $\mathrm{PBC} \rightarrow \mathrm{IN}$ & Ajzen (1991) \\
\hline H8 & $\begin{array}{l}\text { Motivation has a significant effect on } \\
\text { intention }\end{array}$ & $\mathrm{MO} \rightarrow \mathrm{IN}$ & $\begin{array}{l}\text { Seacat and Northrup } \\
(2010)\end{array}$ \\
\hline H9 & $\begin{array}{l}\text { Intention has a significant effect on } \\
\text { disposal behavior }\end{array}$ & $\mathrm{IN} \rightarrow \mathrm{DB}$ & Ajzen (1991) \\
\hline
\end{tabular}

\subsection{Questionnaire Design and Data Collection}

The model used in this study consists of 26 operating variables, which were developed based on the literature review and discussions with experts (academics who work in the field of analysis). The questionnaire consisted of 50 questions that used a seven-point Likert scale, which ranged from 1 (strongly disagree) to 7 (strongly agree). The participants in this study were residents of Jakarta, which has an estimated population of over 10 million people and accommodates 1.38 million commuters from other cities in the Greater Jakarta region daily (Irawan and Pragesari, 2014). With its very dense population, Jakarta produced almost 7,099,080 $\mathrm{m}^{3}$ of waste per day in 2016, though there is no record of the exact amount of WEEE generated (Hutabarat and Ilyas, 2017; Purba et al., 2017).

Table 2 Demographic variables

\begin{tabular}{lcc}
\hline Demographic variables & $\mathrm{N}$ & Percentage \\
\hline Age (years) & & \\
\hline $17-20$ & 337 & $56 \%$ \\
$21-30$ & 241 & $40 \%$ \\
$31-40$ & 6 & $1 \%$ \\
$41-50$ & 9 & $2 \%$ \\
$51-60$ & 4 & $1 \%$ \\
\hline Education level & & \\
\hline High school and below & 397 & $66 \%$ \\
Diploma & 37 & $6 \%$ \\
Bachelor & 151 & $25 \%$ \\
Master and doctoral & 9 & $3 \%$ \\
\hline Income & & \\
\hline IDR1,000,000 & 317 & $53 \%$ \\
IDR1,000,001-IDR3,000,000 & 170 & $28 \%$ \\
IDR3,000,001-IDR6,000,000 & 77 & $13 \%$ \\
$\geq$ IDR6,000,001 & 33 & $6 \%$ \\
\hline
\end{tabular}


The questionnaire used in this study gathered 597 respondents, of which 59\% were female (Table 2). Utmost effort was made to ensure that the study sample represented Jakarta's demographic profile, including the ratio of respondents' sex, ages of mobile phone users, and representation from each region. However, because of time and resource constraints, this study had to satisfy itself with fulfilling the requirements for structural equation modeling (SEM), while attempting to maintain a representative demographic profile. To use SEM accurately, a minimum of 200-400 samples are required (Jackson, 2001). Therefore, a sample size of 597 was considered acceptable as the basis for this analysis. When data from the first 65 respondents was tested it was revealed that all model constructs fulfilled the requirement of Cronbach's alpha $\alpha \geq 0.6$ (Hinton et al., 2014).

\section{Results and Discussion}

\subsection{Results of the Measurement Model Test}

The measurement models were tested using the confirmatory factor analysis (CFA) method. The CFA method aims to find the factor loading of each variable and check the goodness of fit (GOF) of the measurement models. Variables with a factor loading of less than 0.5 were considered not significant (Igbaria et al., 1997). This test identified five indicators for the keeping behavior, four indicators for the reselling behavior, three variables for the donating behavior, four indicators for the recycling behavior, and four variables for the discarding behavior that had to be deleted from the models. To evaluate the fitness of the measurement models, this study used several indicators, as shown in Table 3. Overall, the results show that all the model indices exceeded the acceptable level.

Table 3 Results of GOF for measurement models

\begin{tabular}{|c|c|c|c|c|c|}
\hline \multirow{2}{*}{ Indicator } & \multicolumn{5}{|c|}{ Model Value and Interpretation } \\
\hline & Keeping & Reselling & Donating & Recycling & Discarding \\
\hline $\begin{array}{l}\text { Relative Chi- } \\
\text { Squared }\end{array}$ & $\begin{array}{c}3.39 \\
\text { (good fit) }\end{array}$ & $\begin{array}{c}3.72 \\
\text { (good fit) }\end{array}$ & $\begin{array}{c}4.05 \\
\text { (good fit) }\end{array}$ & $\begin{array}{c}4.08 \\
\text { (good fit) }\end{array}$ & $\begin{array}{c}4.05 \\
\text { (good fit) }\end{array}$ \\
\hline $\begin{array}{l}\text { Goodness-of-Fit } \\
\text { Index (GFI) }\end{array}$ & $\begin{array}{c}0.898 \\
\text { (marginal fit) }\end{array}$ & $\begin{array}{c}0.888 \\
\text { (marginal fit) }\end{array}$ & $\begin{array}{c}0.879 \\
\text { (marginal fit) }\end{array}$ & $\begin{array}{c}0.875 \\
\text { (marginal fit) }\end{array}$ & 0.87 (marginal fit) \\
\hline $\begin{array}{l}\text { Normed Fit Index } \\
\text { (NFI) }\end{array}$ & $\begin{array}{c}0.869 \\
\text { (marginal fit) }\end{array}$ & $\begin{array}{c}0.885 \\
\text { (marginal fit) }\end{array}$ & $\begin{array}{c}0.882 \\
\text { (marginal fit) }\end{array}$ & $\begin{array}{c}0.864 \\
\text { (marginal fit) }\end{array}$ & 0.865 (marginal fit) \\
\hline $\begin{array}{l}\text { Comparative Fit } \\
\text { Index (CFI) }\end{array}$ & $\begin{array}{c}0.903 \\
\text { (good fit) }\end{array}$ & $\begin{array}{c}0.913 \\
\text { (good fit) }\end{array}$ & $\begin{array}{c}0.910 \\
\text { (good fit) }\end{array}$ & $\begin{array}{c}0.893 \\
\text { (marginal fit) }\end{array}$ & 0.894 (marginal fit) \\
\hline $\begin{array}{l}\text { Incremental Fit } \\
\text { Index (IFI) }\end{array}$ & $\begin{array}{c}0.904 \\
\text { (good fit) }\end{array}$ & $\begin{array}{c}0.913 \\
\text { (good fit) }\end{array}$ & $\begin{array}{c}0.911 \\
\text { (good fit) }\end{array}$ & $\begin{array}{c}0.894 \\
\text { (marginal fit) }\end{array}$ & 0.895 (marginal fit) \\
\hline $\begin{array}{l}\text { Relative Fit Index } \\
\text { (RFI) }\end{array}$ & $\begin{array}{c}0.845 \\
\text { (marginal fit) }\end{array}$ & $\begin{array}{c}0.865 \\
\text { (marginal fit) }\end{array}$ & $\begin{array}{c}0.861 \\
\text { (marginal fit) }\end{array}$ & $\begin{array}{c}0.840 \\
\text { (marginal fit) }\end{array}$ & 0.841 (marginal fit) \\
\hline
\end{tabular}

\subsection{Results of Path Analysis}

The next step was to assess whether one latent variable had a significant influence on another latent variable. A relationship between two variables is significant if the $p$-value is less than or equal to 0.05 . The path coefficient for each hypothesis is compiled in Table 4 .

In the model for predicting the keeping behavior, of the nine hypotheses that were subjected to the test, seven were accepted. Subjective norm had no significant influence on intention. This appears to be because keeping a waste mobile phone is a private behavior that is usually unseen by anyone else. The decision to hold a waste mobile phone can also be a result of the personal attachment of the owner to the phone. 
Table 4 Results of path coefficients

\begin{tabular}{|c|c|c|c|c|c|c|c|c|c|c|c|c|}
\hline \multirow{2}{*}{\multicolumn{3}{|c|}{$\begin{array}{l}\text { Model Relationship } \\
\text { (Significant at p- } \\
\text { value }<0.05 \text { ) }\end{array}$}} & \multicolumn{2}{|c|}{ Keeping } & \multicolumn{2}{|c|}{ Reselling } & \multicolumn{2}{|c|}{$\overline{\text { Donating }}$} & \multicolumn{2}{|c|}{ Recycling } & \multicolumn{2}{|c|}{ Discarding } \\
\hline & & & \multirow{2}{*}{$\begin{array}{r}\begin{array}{r}\text { Path } \\
\text { Coef. }\end{array} \\
0.28\end{array}$} & \multirow{2}{*}{$\begin{array}{c}\begin{array}{c}\mathrm{p}- \\
\text { value }\end{array} \\
0.000\end{array}$} & \multirow{2}{*}{$\begin{array}{l}\text { Path } \\
\text { Coef. } \\
0.279\end{array}$} & \multirow{2}{*}{$\begin{array}{c}\begin{array}{c}\mathrm{p}- \\
\text { value }\end{array} \\
0.000\end{array}$} & \multirow{2}{*}{$\begin{array}{l}\text { Path } \\
\text { Coef. } \\
0.253\end{array}$} & \multirow{2}{*}{$\begin{array}{c}\begin{array}{c}\mathrm{p}- \\
\text { value }\end{array} \\
0.000\end{array}$} & \multirow{2}{*}{$\begin{array}{r}\begin{array}{r}\text { Path } \\
\text { Coef. }\end{array} \\
0.24\end{array}$} & \multirow{2}{*}{$\begin{array}{c}\begin{array}{c}\mathrm{p}- \\
\text { value }\end{array} \\
0.000\end{array}$} & \multirow{2}{*}{$\begin{array}{c}\begin{array}{l}\text { Path } \\
\text { Coef. }\end{array} \\
0.287\end{array}$} & \multirow{2}{*}{$\begin{array}{c}\begin{array}{c}\mathrm{p}- \\
\text { value }\end{array} \\
0.00\end{array}$} \\
\hline EA & $\rightarrow$ & AT & & & & & & & & & & \\
\hline EA & $\rightarrow$ & EK & 0.516 & 0.000 & 0.515 & 0.000 & 0.607 & 0.000 & 0.54 & 0.000 & 0.511 & 0.000 \\
\hline EK & $\rightarrow$ & AT & 0.559 & 0.000 & 0.563 & 0.000 & 0.572 & 0.000 & 0.609 & 0.000 & 0.552 & 0.000 \\
\hline EK & $\rightarrow$ & MO & 0.125 & 0.011 & 0.195 & 0.000 & 0.495 & 0.000 & 0.597 & 0.000 & -0.085 & $0.083^{*}$ \\
\hline $\mathrm{AT}$ & $\rightarrow$ & IN & 0.026 & $0.526^{*}$ & 0.062 & $0.06^{*}$ & 0.064 & $0.113^{*}$ & -0.82 & 0.092 & -0.079 & 0.024 \\
\hline SN & $\rightarrow$ & IN & -0.001 & $0.982^{*}$ & 0.016 & $0.681^{*}$ & 0.059 & $0.143^{*}$ & 0.116 & 0.009 & 0.215 & 0.000 \\
\hline PBC & $\rightarrow$ & IN & 0.132 & 0.01 & 0.015 & $0.779^{*}$ & 0.048 & $0.274^{*}$ & 0.183 & 0.000 & 0.089 & 0.043 \\
\hline MO & $\rightarrow$ & IN & 0.574 & 0.000 & 0.855 & 0.000 & 0.758 & 0.000 & 0.697 & 0.000 & 0.672 & 0.000 \\
\hline IN & $\rightarrow$ & DB & 0.777 & 0.000 & 0.786 & 0.000 & 0.798 & 0.000 & 0.726 & 0.000 & 0.596 & 0.000 \\
\hline
\end{tabular}

Note: *not significant at $p$-value $<0.05$

Moreover, attitude has no crucial impact on intention because of unfamiliarity regarding how to dispose of mobile phones. In the model for predicting the reselling behavior, six of the nine hypotheses were accepted. Of the accepted hypotheses, subjective norm did not have a significant impact on intention for the reselling behavior. Reselling an end-of-life mobile phone can be motivated by the desire for money; however, attitude did not have a substantial effect on either keeping or reselling. The difference is that perceived behavior control was not significant in influencing intention of reselling.

In the model for predicting the donating behavior, six of the nine hypotheses were accepted. Subjective norm did not have a significant influence on the intention of such behavior. Like reselling behavior, subjective norm, attitude, and perceived behavior control had no significant influence on intention. Awareness of social needs stems from a person's internal value code, which often cannot be influenced by other people's opinions. In the model of predicting the recycling behavior, of the nine hypotheses that were subjected to the test, all of them were accepted. This finding was in line with the findings of previous studies (de la Vega, 2004; Seacat and Northrup, 2010; Aminrad et al., 2013; Goudeau, 2014).

In the model for predicting the discarding behavior, of the nine hypotheses that were tested, eight were accepted. Environmental knowledge did not have a significant relationship with the motivation for discarding behavior. Although citizens know about the dangers of discarding waste mobile phones with other garbage, they are still not concerned enough about the environmental impacts of this action.

Table 4 depicts an interesting finding: the keeping, reselling, donating, and recycling models all have the same valid pathway that can predict disposal behaviors $(\mathrm{EA} \rightarrow \mathrm{EK} \rightarrow \mathrm{MO}$ $\rightarrow$ IN $\rightarrow$ DB). This pathway means that increasing environmental awareness in society could deepen the knowledge of ecological issues. This could then increase motivation to deal with environmental problems, influencing consumers' intentions to act accordingly. This finding indicates one possible method for promoting responsible disposal behaviors. Notably, this pathway is not valid for the discarding model, in which the pathway from environmental awareness to disposal behaviors is EA $\rightarrow$ EK $\rightarrow$ AT $\rightarrow$ IN $\rightarrow$ DB. With this pathway, the practice of throwing waste mobile phones into mixed bins would be solidified into a habit in the city of Jakarta. 


\section{Conclusions}

The model in this study was developed based on the TPB model and tested based on a survey conducted in Jakarta, the capital of Indonesia. This survey revealed several noteworthy findings. In all the models, environmental awareness had a significant effect on environmental knowledge. Environmental knowledge itself significantly influences attitude. Motivation has a substantial influence on intention, while intention has a significant impact on all types of disposal behaviors. Therefore, environmental knowledge significantly affects individuals' motivations for keeping, reselling, donating, or recycling waste mobile phones. Additional significant factors include: subjective norm, which has an influence on individuals' intention of recycling or discarding mobile phones; perceived behavioral control which has a significant influence on the behaviors of keeping, recycling, or discarding waste mobile phones; and attitude, which has a significant impact on the intentions of recycling or discarding waste mobile phones.

There are several limitations in this study that offer directions for future improvement. This study focused solely on the residents of the city of Jakarta, excluding other areas in the Greater Jakarta area (i.e., Bogor, Depok, Tangerang, and Bekasi). These cities are effectively linked into one urban area through the daily movement of thousands of workers. Moreover, most of the respondents in this study were in the age range of 17-30 years, commonly classified as Generation Y (i.e., Millennials) and Generation Z. It would be interesting if a future study could perform a multigenerational analysis, completing the data with the Baby Boomer generation.

\section{References}

Ajzen, I., 1991. The Theory of Planned Behavior. Organizational Behavior and Human Decision Processes, Volume 50(2), pp. 179-211

Aminrad, Z., Zarina, S., Sayed Zakariya, B., Hadi, A.S., Sakari, M., 2013. Relationship between Awareness, Knowledge and Attitudes towards Environmental Education among Secondary School Students in Malaysia. World Applied Sciences Journal, Volume 22(9), pp. 1326-1333

Anvari, R., Huzaid, N.S.B.J., Miri, S.A., Chermahini, S.H., 2013. Mediating Effect of Psychological Contract in the Relationship between Learning and Development Initiatives and Engineers' Intention to Stay. Review of European Studies, Volume 5(5), pp. 233-237

Ardi, R., 2016. Waste Electrical and Electronic Equipment (WEEE) Management Systems in the Developed and the Developing Countries: A Comparative Structural Study. Doctoral Dissertation. University of Duisburg-Essen, Duisburg. Retrieved from https://duepublico2.uni-due.de/receive/duepublico_mods_00042513

Ardi, R., Leisten, R., 2016. Assessing the Role of Informal Sector in WEEE Management Systems: A System Dynamics Approach. Waste Management, Volume 57, pp. 3-16

Ari, E., Yilmaz, V., 2016. A Proposed Structural Model for Housewives' Recycling Behavior: A Case Study from Turkey. Ecological Economics, Volume 129, pp. 132-142

Athman, J.A., Monroe, M.C., 2001. Elements of Effective Environmental Education Programs. Defining Best Practices in Boating, Fishing, and Stewardship Education, pp. 37-48

Baldé, C.P., Wang, F., Kuehr, R., Huisman, J., 2017. The Global E-waste Monitor 2017: Quantities, Flows, and Resources. United Nations University

Baxter, J., Gram-Hanssen, I., 2016. Environmental Message Framing: Enhancing Consumer Recycling of Mobile Phones. Resources, Conservation and Recycling, Volume 109, pp. 96-101 
Borthakur, A., Govind, M., 2018. Public Understandings of E-Waste and Its Disposal in Urban India: From a Review towards a Conceptual Framework. Journal of Cleaner Production, Volume 172, pp. 1053-1066

Borthakur, A., Govind, M., 2017. Emerging Trends in Consumers' E-waste Disposal Behaviour and Awareness: A Worldwide Overview with Special Focus on India. Resources, Conservation and Recycling (Part B), Volume 117, pp. 102-113

Chi, X., Wang, M.Y.L., Reuter, M.A., 2014. E-Waste Collection Channels and Household Recycling Behaviors in Taizhou, China. Journal of Cleaner Production, Volume 80, pp. 87-95

Cucchiella, F., D’Adamo, I., Lenny Koh, S.C., Rosa, P., 2016. A Profitability Assessment of European Recycling Processes Treating Printed Circuit Boards from Waste Electrical and Electronic Equipments. Renewable and Sustainable Energy Reviews, Volume 64, pp. 749-760

de la Vega, R.M.C.L., 2004. Awareness, Knowledge, and Attitude about Environmental Education: Responses from Environmental Specialists, Highschool Instructors, Students and Parents. Doctoral Dissertation. University of Central Florida, Orlando, Florida. Retrieved from https://stars.library.ucf.edu/etd/178/

Devina, H., 2018. Welcome to the 'Most Generous Country' in the World: Indonesia. Jakarta Post. Retrieved from https://www.thejakartapost.com/news/2018/11/02/welcometo-the-most-generous-country-in-the-world-indonesia.html

Echegaray, F., Hansstein, F.V., 2017. Assessing the Intention-Behavior Gap in Electronic Waste Recycling: the Case of Brazil.Journal of Cleaner Production, Volume 142, pp. 180190

Gilal, F.G., Zhang, J., Gilal, N.G., Gilal, R.G., 2019. Linking Self-determined Needs and Word of Mouth to Consumer E-Waste Disposal Behaviour: A Test of Basic Psychological Needs Theory. Journal of Consumer Behavior, Volume 18(1), pp. 12-24

Goudeau, C. V., 2014. Ready to Tear? A Study on Fashion and Consumer Disposal Behavior. Doctoral Dissertation. Oklahoma State University, Stillwater, Oklahoma. Retrieved from

https://shareok.org/bitstream/handle/11244/14854/Goudeau_okstate_0664D_134 87.pdf?sequence $=1$

Hinton, P.R., McMurray, I., Brownlow, C., 2014. SPSS Explained. $2^{\text {nd }}$ Edition. Routledge, Hove, East Sussex

Hutabarat, L.E., Ilyas, T., 2017. Mapping of Land Subsidence Induced by Groundwater Extraction in Urban Areas as Basic Data for Sustainability Countermeasures. International Journal of Technology, Volume 8(6), pp. 1001-1011

Igbaria, M., Zinatelli, N., Cragg, P., Cavaye, A.L.M., 1997. Personal Computing Acceptance Factors in Small Firms: A Structural Equation Model. MIS Quarterly, Volume 21(3), pp. 279-305

Irawan, H., Pragesari, N.N., 2014. Statistik Komuter Jabodetabek: Hasil Survei Komuter Jabodetabek 2014 (Statistics of Jabodetabek Commuters: the Survey Results on Commuters in 2014), Statistics Indonesia. Retrieved from https://www.bps.go.id/publication/2014/03/17/c0deaf751b807b56681a9860/stati stik-komuter-jabodetabek--hasil-survei-komuter-jabodetabek-2014-.html

Jackson, D.L., 2001. Sample Size and Number of Parameter Estimates in Maximum Likelihood Confirmatory Factor Analysis: A Monte Carlo Investigation. Structural Equation Modeling: A Multidisciplinary Journal, Volume 8(2), pp. 205-223 
Jacoby, J., Berning, C.K., Dietvorst, T.F., 1977. What about Disposition?. Journal of Marketing, Volume 41(2), pp. 22-28

Kochan, C.G., Prybutok, V.R., 2016. Determinants and Logistics of E-Waste Recycling. The International Journal of Logistics Management, Volume 27(1), pp. 52-70

Li, B., Yang, J., Song, X., Lu, B., 2012. Survey on Disposal Behaviour and Awareness of Mobile Phones in Chinese University Students. Procedia Environmental Sciences, Volume 16, pp. 469-476

Magista, M., Dorra, B.L., Pean, T.Y., 2018. A Review of the Applicability of Gamification and Game-based Learning to Improve Household-level Waste Management Practices among Schoolchildren. International Journal of Technology, Volume 9(7), pp. 14391449

Nnorom, I.C., Ohakwe, J., Osibanjo, O., 2009. Survey of Willingness of Residents to Participate in Electronic Waste Recycling in Nigeria - A Case Study of Mobile Phone Recycling. Journal of Cleaner Production, Volume 17(18), pp. 1629-1637

Pérez-Belis, V., Bovea, M., Ibáñez-Forés, V., 2014. An In-depth Literature Review of the Waste Electrical and Electronic Equipment Context: Trends and Evolution. Waste Management and Research, Volume 33(1), pp. 3-29

Polák, M., Drápalová, L., 2012. Estimation of End of Life Mobile Phones Generation: The Case Study of the Czech Republic. Waste Management, Volume 32(8), pp. 1583-1591

Prabowo, B., Simanjuntak, F.S.H., Saldi, Z.S., Samyudia, Y., Widjojo, I.J., 2019. Assessment of Waste to Energy Technology in Indonesia: A Techno-economical Perspective on a 1000 ton/day Scenario. International Journal of Technology, Volume 10(6), pp. 1228-1234

Purba, W.S., Safitri, P.A., Andianti, R., 2017. Statistik Lingkungan Hidup Indonesia 2017. (Environment Statistics of Indonesia 2017). Statistics Indonesia. Retrieved from https://www.bps.go.id/publication/2017/12/21/4acfbaac0328ddfcf8250475/statist ik-lingkungan-hidup-indonesia-2017.html

Puspitasari, L., Ishii, K., 2016. Digital Divides and Mobile Internet in Indonesia: Impact of Smartphones. Telematics and Informatics, Volume 33(2), pp. 472-483

Santoso, S., Yuri, M., Zagloel, T., Ardi, R., Suzianti, A., 2019. Estimating the Amount of Electronic Waste Generated in Indonesia: Population Balance Model. IOP Conference Series: Earth and Environmental Science, Volume 219, pp. 1-7

Sarath, P., Bonda, S., Mohanty, S., Nayak, S.K., 2015. Mobile Phone Waste Management and Recycling: Views and Trends. Waste Management, Volume 46, pp. 536-545

Seacat, J.D., Northrup, D., 2010. An Information-motivation-behavioral Skills Assessment of Curbside Recycling Behavior. Journal of Environmental Psychology, Volume 30(4), pp. 393-401

Shim, S., 1995. Environmentalism and Consumers' Clothing Disposal Patterns: An Exploratory Study. Clothing and Textiles Research Journal, Volume 13(1), pp. 38-48

Sudarmadi, S., Suzuki, S., Kawada, T., Netti, H., Soemantri, S., Tugaswati, A.T., 2001. A Survey of Perception, Knowledge, Awareness, and Attitude in regard to Environmental Problems in a Sample of Two Different Social Groups in Jakarta, Indonesia. Environment, Development and Sustainability, Volume 3, pp. 169-183

Van der Werff, E., Steg, L., Keizer, K., 2013. It is a Moral Issue: The Relationship between Environmental Self-identity, Obligation-based Intrinsic Motivation and Proenvironmental Behaviour. Global Environmental Change, Volume 23(5), pp. 1258-1265

Wang, Z., Guo, D., Wang, X., 2016. Determinants of Residents' E-Waste Recycling Behaviour Intentions: Evidence from China. Journal of Cleaner Production, Volume 137, pp. 850860 
Wilson, G.T., Smalley, G., Suckling, J.R., Lilley, D., Lee, J., Mawle, R., 2017. The Hibernating Mobile Phone: Dead Storage as a Barrier to Efficient Electronic Waste Recovery. Waste Management, Volume 60, pp. 521-533

$\mathrm{Xu}$, C., Zhang, W., He, W., Li, G., Huang, J., 2016. The Situation of Waste Mobile Phone Management in Developed Countries and Development Status in China. Waste Management, Volume 58, pp. 341-347

$\mathrm{Xu}$, L., Ling, M., Lu, Y., Shen, M., 2017. Understanding Household Waste Separation Behaviour: Testing the Roles of Moral, Past Experience, and Perceived Policy Effectiveness within the Theory of Planned Behaviour. Sustainability, Volume 9(4), pp. 625

Yunita, M.T., Zagloel, T.Y.M., Ardi, R., Zulkarnain, 2019. Development of Funding Model in EWaste Management Systems for Household Products in Indonesia. IOP Conference Series: Earth and Environmental Science, Volume 219, pp. 1-6 